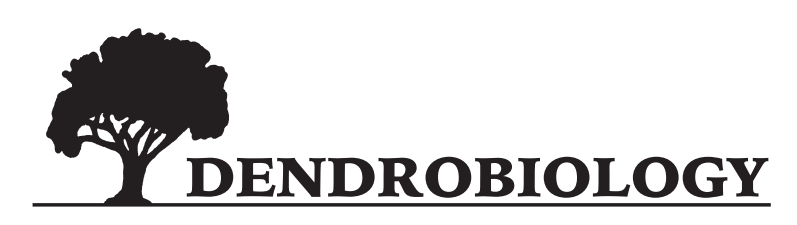

2015, vol. 73, 75-90

http://dx.doi.org/10.12657/denbio.073.008

\author{
Federico Vessella, Antonello Salis, Mattia Scirè, Gianluca Piovesan, \\ Bartolomeo Schirone
}

\title{
Natural regeneration and gender-specific spatial pattern of Taxus baccata in an old-growth population in Foresta Umbra (Italy)
}

Received: 12 May 2014; Accepted: 8 October 2014

\begin{abstract}
English yew is rare and endangered dioecious species. Research on regeneration processes of endangered taxa is important to understand the mechanisms allowing a species to survive under several ecological scenarios, to predict future distribution shifts, to achieve best management practices and conservation policies. Our investigation was focusing on one of the oldest yew population in Europe, in Foresta Umbra in Italy. The main aim of this study was to understand spatial regeneration processes and dynamics related with parent trees' sex distribution.
\end{abstract}

Geostatistical analysis showed that seedlings occur in patches avoiding direct competition with adult yews. Negative relationship between regeneration and yew density and basal area was found.

\begin{abstract}
A general model for the reproductive ecology is proposed: females are less competitive and more environmentally demanding than males, because of their reproductive effort. Indeed, male and female fitness responds differently across environmental gradients, thus favouring spatial segregation of seedlings. Understanding the yew's adaptive effectiveness is essential to ensure the conservation of existing populations, and encourage the species' resilience into areas where yew is endangered.
\end{abstract}

Additional key words: Mediterranean environment, regeneration dynamics, endangered species, dioecy

Address: B. Schirone, Dipartimento di Scienze e Tecnologie per l'Agricoltura, le Foreste, la Natura e l'Energia (DAFNE), Università degli Studi della Tuscia, Via S. Camillo de Lellis, 01100 Viterbo, Italy, e-mail: schirone@unitus.it

\section{Introduction}

English yew (Taxus baccata L.) is a native evergreen non-resinous gymnosperm tree, considered rare and endangered in many European countries. The geographic range of T. baccata extends northwards to Norway and Sweden, southwards to Italy, Spain and
Greece, North Africa, westwards to Azores and Madeira archipelagos, and eastwards to Estonia, Poland, Ukraine, Turkey, and the Caucasus Mountains (Thomas and Polwart 2003; Vessella et al. 2013). Despite a wide distribution range, yew occurrence is often scattered, consisting of small populations or isolated individuals. This is generally due to intensive 
human land-use and to forest management which changed the structure and species composition since the Neolithic Age (Jahn 1991; Svenning and Magård 1999; Thomas and Polwart 2003). Indeed, the main reasons for the decline of yew are widespread deforestation, selective felling, wildfire and browsing by herbivores affecting regeneration as well as weak competitive ability (Bugala 1978; Tittensor 1980; Jahn 1991; Dhar et al. 2007; Schirone et al. 2010; Iszkuło et al. 2012; Linares 2013).

In the last forty years, since the identification of anticancer agents stored in its tissues, a new interest as well as a new potential threat impend over the species (Wani et al. 1971; Horwitz 1992; Nicolaou et al. 1994a, 1994b; Patel et al. 2009; Yin et al. 2010; Zhang et al. 2010). Its pharmaceutical usefulness imparts a great additional economic value, and consequently the need to preserve the species to assure the continuation of this resource and prevent overharvesting to extinction (Katsavou and Ganatsas 2012; Iszkuło et al. 2013; Uniyal 2013).

Several studies have been performed in European forest populations of yew in order to investigate its biology and ecology to define the risks connected to the species survival. In this light, the improvements of knowledge about the factors favouring natural regeneration, which could assure stability or expansion of present yew distribution, are of primary importance (Köpp 1991; Hulme 1996; Boratyński et al. 1997; Giertych 2000; Saniga 2000; Ruprecht et al. 2010; Katsavou and Ganatsas 2012; Linares 2013).

Certain environmental parameters have been related to yew recruitment probabilities under different ecological scenarios. It has been demonstrated that summer drought, low humidity, temperature and light availability affect yew regeneration, seedling survival and growth (Iszkuło and Boratyński 2005; Mendoza et al. 2009; Iszkuło 2010; Perrin and Mitchel 2013; Linares 2013). Spatial analysis of yew regeneration revealed a clear influence of different canopy trees on the percentage of successfully growing individuals (Iszkuło and Boratyński 2004). Indeed, inter- and intra-specific competition is central on regeneration distribution and abundance; in fact some of the tree genera forming canopies around yew are strong competitors for nutrients and water availability lowering seedling survival rate (Massey 1925; Bode 1958; Vandermast et al. 2002). In particular, the capability of yew to release allelopathic substances, able to reduce seed germination and seedlings development at their initial growth stages has been reported (Thomas and Polwart 2003; Iszkulo et al. 2012). Moreover, the growth of young generations is also limited under old yew trees (Iszkuło and Boratyński 2004; Iszkuło et al. 2012), although this negative influence has not been recorded in sparse mother tree populations (Svenning and Magård 1999).
In Italy, three studies have been carried out to explain different features concerning yew ecology and regeneration (Farris and Filigheddu 2008; Piovesan et al. 2009; Farris et al. 2012). In particular it has been shown that yew regeneration in the land site was directly related to the basal area of the yew trees. At a local scale, presence of established trees favoured regeneration in relatively less developed stands, whereas high density of mature yews suppressed regeneration. As yew density increased, regeneration decreased, so that yew conservation can not be limited to presently-occurring populations, despite the longevity and potential for vegetative reproduction of the species. In fact, long-term existence of yew depends on maintaining and expanding old-growth beech forests that include yew patches, displaying a minimum continuous cover equivalent to a relatively undisturbed forest (Piovesan et al. 2009).

These works are very important for achieving best management practices and conservation policies, but they need further improvements, since yew is a dioecious species.

Reproductive ecology of dioecious species is considered relevant for research concerning adaptive mechanisms and plant evolution, especially in relation to pollination (Freeman et al. 1997), seed dispersal (Givnish 1980), colonization processes and vegetational succession (Faliński 1980). Indeed, sex ratio is fundamental because it can show adaptability to particular environmental conditions. Males prevail under stressful circumstances in many species, even if the opposite may sometimes be observed (Freeman et al. 1981; Arista et al. 1997; Obeso 2002; Nuñez et al. 2008). It is generally accepted that reproductive effort is higher for female than male individuals (Krischik and Denno 1990a, 1990b; Cipollini and Stiles 1991; Massei et al. 2006; Montesinos et al. 2006; Zunzunegui et al. 2006), because the higher energetic costs for females result in lower yearly increments of height and stem diameter, and consequently, higher mortality under stress conditions (Sawyer and Anderson 1998; Espirito-Santo et al. 2003; Massei et al. 2006). Such a pattern has been found to be more frequent than the reverse in dioecious plant species, resulting in male-biased sex ratios (Faliński 1998; Bañuelos and Obeso 2004; de Jong and van der Meijden 2004).

Iszkuło et al. (2009; 2011) have recently studied the sex distribution and sexual dimorphism in $T$. baccata among central-European populations; the authors pointed out that the sex ratio in populations of particular plant species can change as a population ages and plant communities undergo succession. The possibility of the loss of ability to compete with males is negative consequences of higher reproduction effort for T. baccata females, which are also more sensitive to stressful environments than males. 
These consequences are generally more visible in populations on the species range limits, where climatic changes have a greater impact on their development, and in older populations where male-biased sex ratios are frequently observed (c.f. Klinkhamer and de Jong 1997; Faliński 1998; Baldoni et al. 2004; Bañuelos and Obeso 2004). This situation could be enhanced by specific setting of $T$. baccata populations as in the case of restricted areas with little diversification within sites (Iszkuło et al. 2009; Cedro and Iszkuło 2011).

On the other side, in the Mediterranean Basin the species' behaviour is not very well known; references about the regeneration processes are still few (e.g. Katsavou and Ganatsas 2012), while investigations about the relationship between regeneration and parent tree sex are absent. The present study might contribute towards delineating a general model also comprehensive of the Mediterranean Basin. The yew population at Foresta Umbra, located at Gargano peninsula (Apulia, Italy) has been considered as reference for this work, also because it represents one of the oldest yew population in Europe (Rößner 2009). The performed analysis will focus on the regeneration processes and dynamics in an old-growth forest with additional consideration of the role of plant sex.

\section{Materials and methods}

\section{Site description}

In the peninsular territory of Italy, Taxus baccata generally occupies the understory of beech forests with Ilex aquifolium (a priority habitat named "Apennine beech forests with Taxus and Ilex" - *9210; EU Regulation 92/43) along the Apennines, mainly in the centre-south, with isolated occurrences in Sicily, usually above $900 \mathrm{~m}$ of altitude (Fig. 1). In some areas yew can arise in forests without beech, e.g. in Sardinia (cf. Phillyreo latifoliae-Taxetum baccatae and Cyclamino repandi-Taxetum baccatae), in Calabria and Sicily (Ilici-Taxetum baccatae) (Brullo et al. 1996, 2001; Bacchetta and Farris 2006; Farris et al. 2012). In particularly humid conditions Taxus and Ilex can

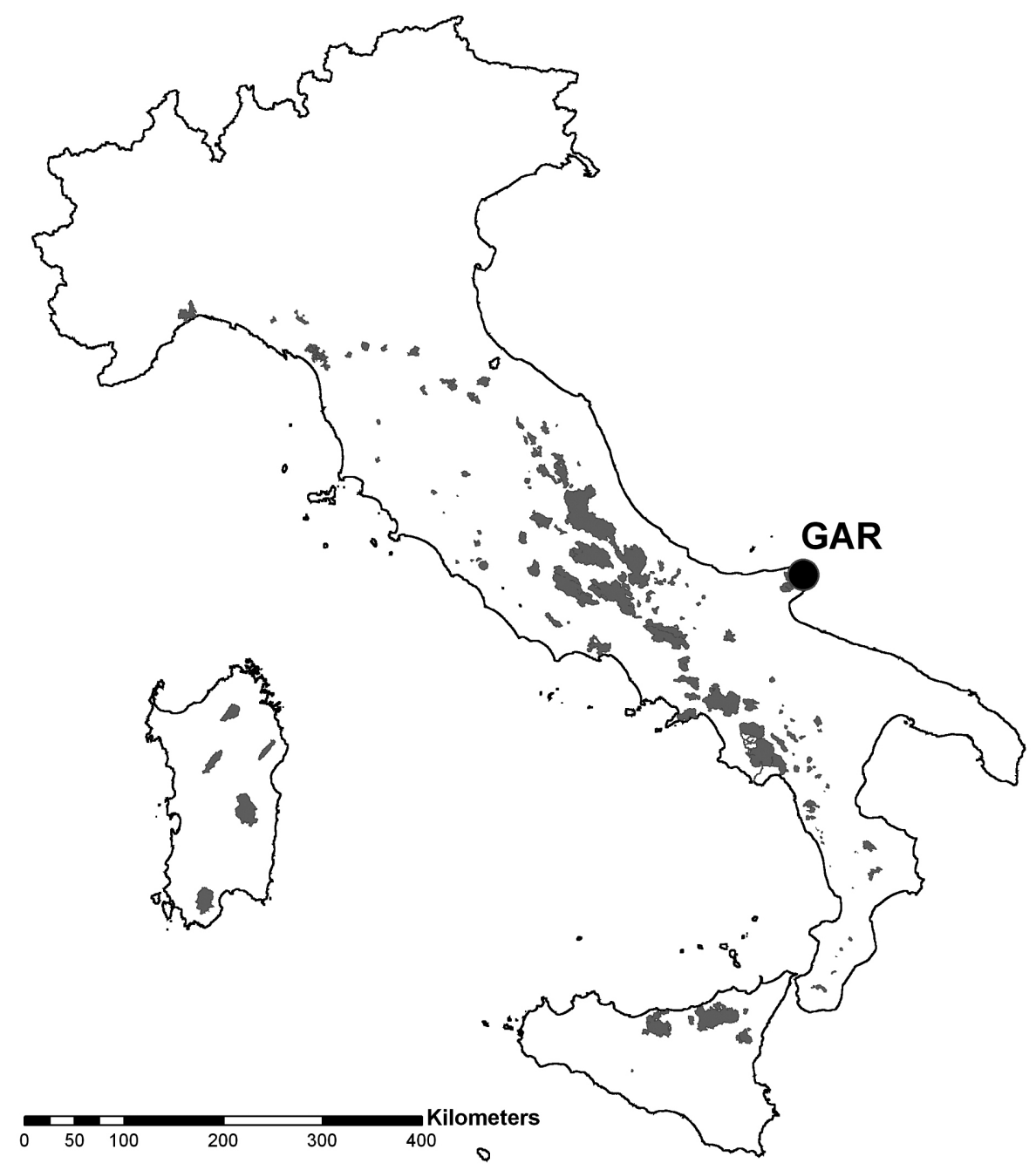

Fig. 1. Map showing the location of Foresta Umbra study area at Gargano peninsula (black solid circle) with distribution map of priority habitat "Apennine beech forests with Taxus and Ilex" - *9210 in protected areas (gray polygons) 
also be found at $500 \mathrm{~m}$, relicts of the Cenozoic flora, characterised by warm-humid climatic conditions, survived the glaciations of the Quaternary period in refugial areas, and may have followed Fagus in the successive post glacial expansion (Magri et al. 2006; Scarnati et al. 2009).

Gargano is a geographical sub-region of Apulia, consisting in a wide isolated mountain massif made of highland and picks forming the backbone of a promontory projecting into the Adriatic Sea. It is made by a block of uplifted Jurassic and Cretaceous limestones (Martinis 2003). This peninsula is partially covered by the remains of an ancient forest, of which Foresta Umbra (11.000 ha of mixed beech forest) is the best representation.

The study area has a surface of 341 ha located in the core of Foresta Umbra $\left(41^{\circ} 48 ' 34^{\prime \prime} \mathrm{N} ; 1^{\circ} 59^{\prime} 38^{\prime \prime} \mathrm{E}\right.$, see Fig. 1), at the Municipality of Monte S. Angelo. Elevation ranges from $730 \mathrm{~m}$ to $820 \mathrm{~m}$ a.s.l. The climate is Mediterranean montane (oro-Mediterranean) with annual precipitation around $1150 \mathrm{~mm}$, mean annual temperature around $11.8{ }^{\circ} \mathrm{C}$, and summer drought stress in June and July. However, precipitation and temperature can differ at local scale, depending on the topographic features. Soil substrate is deep and fertile (brown soil), with rocky zones widespread at south-east and south-west.

Yew normally occurs as an understory species below the beech canopy, in scattered groups or widespread isolated individuals. Co-occurring tree species take part in forest coenosis, according to relative humidity and altitude, and include European hornbeam (Carpinus betulus L.), Italian maple (Acer obtusatum Waldst. and Kit. ex Willd), field maple (Acer campestre L.), sycamore maple (Acer pseudoplatanus L.), European holly (Ilex aquifolium L.), chequers tree (Sorbus torminalis (L.) Crantz.), manna ash (Fraxinus ornus L.) and European hop-hornbeam (Ostrya carpinifolia Scop.).

Nowadays, Foresta Umbra is managed as protected area, thus it is following a natural vegetation succession since silvicultural practices stopped in 1971 and are still forbidden.

\section{Field surveys}

At Foresta Umbra a total census of yew (established trees, ET) with stem diameter at breast height $(\mathrm{DBH}) \geq 3 \mathrm{~cm}$ has been performed in 2004; diameter, height, sex determination, habitus (monocormic or policormic), general description and GPS position have been recorded for 1023 adult trees. DBH for policormic trees has been recorded as average of diameters of all trunks.

Regeneration, i.e. plants with $\mathrm{DBH}<3 \mathrm{~cm}$, was recorded in the whole area, and subdivided in 4 height classes. Seedlings (R0) presented a height $<5 \mathrm{~cm}$, while saplings of height $\geq 5 \mathrm{~cm}$ were further divided in 3 classes: $5-25 \mathrm{~cm}$ (R1), 25-120 cm (R2), and > $120 \mathrm{~cm}$ (R3). Regeneration abundance (plants/ha) was also estimated based on a $20 \times 20$ m grid cells and subdivided in 3 classes: $<250$ plants/ha (A1, scarce), 250-1000 plants/ha (A2, intermediate) and $>1000$ plants/ha (A3, abundant). Coordinates of the upper-left corner of each cell containing regeneration were also recorded using a GPS receiver.

Forest structure of all woody species at study area was quantified using 12 randomly located circular plots with a $15 \mathrm{~m}$ radius; within each plot, with an overstorey composed by Fagus sylvatica and Carpinus betulus, the total amount of seedlings and saplings for each species were counted as well as $\mathrm{DBH} \geq 3 \mathrm{~cm}$.

\section{Laboratory analysis}

Geographical analyses of Foresta Umbra were performed using ESRI ArcMap software version 9.1. Topographic maps at 1:10000 scale for Gargano were used to produce a Digital Elevation Model (DEM). Coordinates of established trees and regeneration cells were then plotted on the DEM to quantify elevation, slope and exposure. To summarize the data, the term "overall" has been used for describing the entire area (including cells without yew) occupied by the yew population. The perimeter of yew distribution was drawn as a polygon connecting the outer cells with yew plants. Mean cell density, and mean cell basal area (BA) for ET were computed using only cells containing yew. BA is defined as the area of a given section of land occupied by the cross-section of tree trunks and stems at their base. Such a measurement is generally taken at the DBH.

Sex determination was used to split the population in three classes: male (M), female (F) and undetermined (U, i.e. trees with no sex expression).

Spatial analysis of sex distribution, including the geographic directional distribution, was computed producing three standard deviational ellipses centered on the mean centres; this method allowed to measure the trend for selected points by calculating the standard deviation of $\mathrm{x}$ and $\mathrm{y}$ coordinates, by defining the axes of the ellipse and estimating if a distribution had a particular orientation by the elongation of the ellipse. Moreover, the density of each sex class was calculated using an approximate Gaussian kernel function (Silverman 1986). Conceptually, a smoothly curved surface is fitted over each point of the dataset. The surface values decrease with increasing distance from each point, according to the Gaussian distribution, reaching zero at the maximum radius distance. The density value at each raster cell is estimated by adding the values of all kernel surfaces where they overlay the raster cell center, according to the quadratic kernel function. 
Regeneration abundance classes were overlapped to the BA classes, and numerical data analysis, including fitting relationships and contingency table were calculated using Microsoft Excel 2003. To estimate the relationship between regeneration and adult tree presence, an intersect function of both distributions was run in ArcMap, using $5 \mathrm{~m}$ buffer tolerance for ET and result was plotted in a histogram using Microsoft Excel 2003.

The Magini regeneration index (Ir) (Magini 1967) was calculated for yew using data from circular plots. This index equals the seedlings density per $\mathrm{m}^{2}$ multiplied by its mean height in $\mathrm{cm}$. Relationships between regeneration abundance and exposure, slope (three classes: $<10 \%, 10-20 \%,>20 \%$ ) and rockiness (three classes: $<10 \%, 10-20 \%,>20 \%$ ) were estimated using $\chi^{2}$ test. Other correlations were calculated using Spearman rank correlation coefficient $\left(\mathrm{r}_{\mathrm{s}}\right)$ involving Ir and basal area of main overstorey species (Fagus sylvatica and Carpinus betulus), total ba- sal area, density, mean $\mathrm{DBH}$ and height of the whole population, and total amount of plants per hectare of beech and hornbeam, as well as the regeneration abundance relationship with mean DBH and height of the population.

Spatial patterns and gradient analysis were further investigated using variograms for testing spatial dependence (Fortin and Dale 2005) in yew sapling abundance (A classes) and basal area $\left(\mathrm{m}^{2} / \mathrm{ha}\right)$. Besides univariate variograms, which are based on values of the same variable at different locations, a bivariate variogram (cross-variogram) was also used, which considers values of two variables (yew basal area and sapling abundance) at different locations to find how they covary spatially (Dimov et al. 2005). Unlike a variogram, a cross-variogram can take negative values (see Maestre et al. 2005) when an increase of one variable corresponds, on average, to a decrease of the other variable for a given separation distance. Sample variograms and cross-variogram

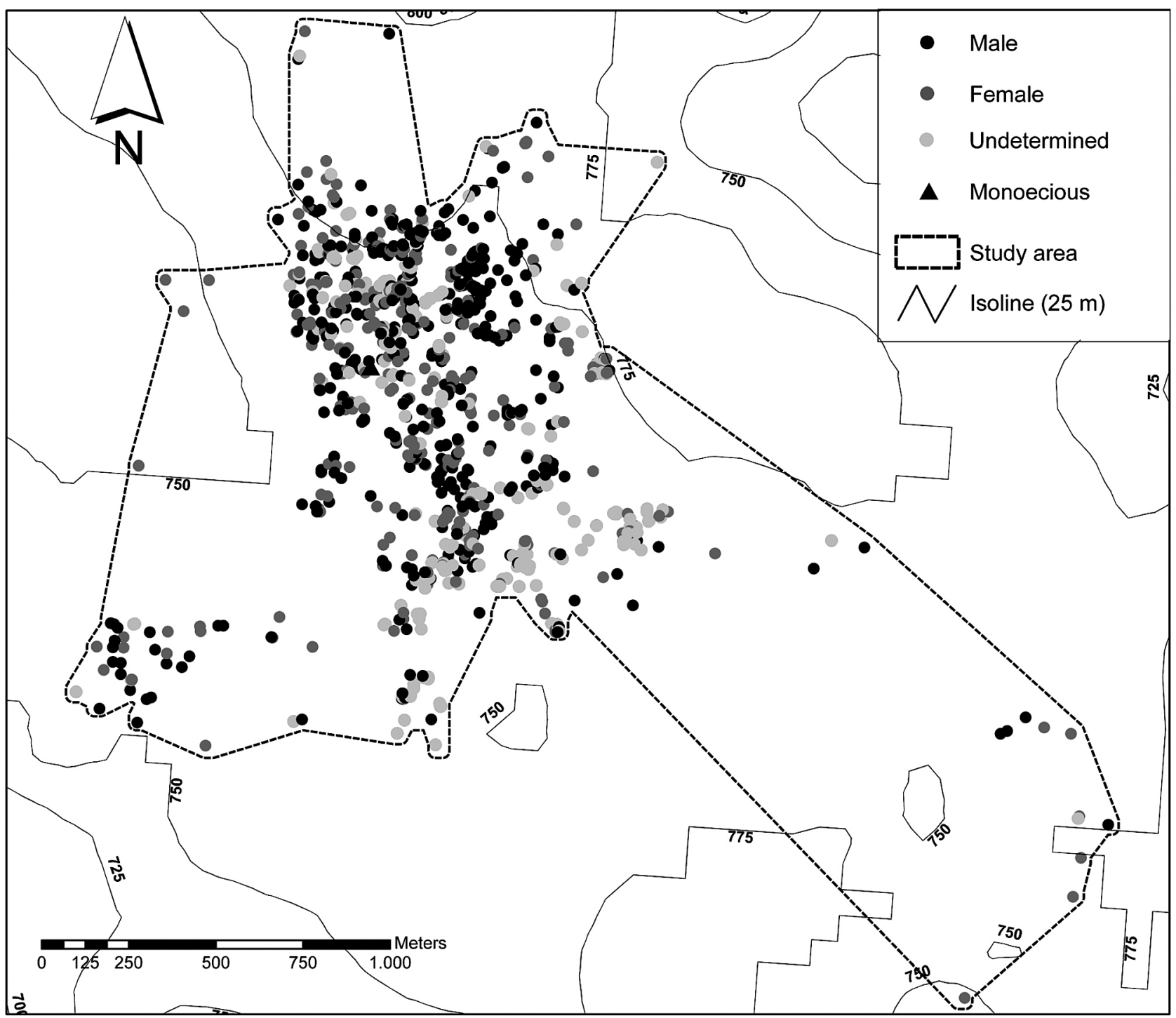

Fig. 2. Distribution map of established trees (ET) by sex classes at Foresta Umbra study area 
were estimated using $20 \mathrm{~m}$ distance classes up to a maximum distance of $250 \mathrm{~m}$. The coefficient of determination $\left(\mathrm{R}^{2}\right)$ was examined to determine how the model variogram fitted the sample variogram. Variogram parameters (nugget, range, and sill) computed from the fitted theoretical model were used for comparing variables and sites. The amount of spatial dependence (SPD; \%) was obtained from the ratio between the sill and the sum of nugget and sill. The software package used for geostatistical analysis was GS+ version 8 (Gamma Design Software 2009).

\section{Results}

Occurrence of yew at Foresta Umbra study area is defined by a dense nucleus on a surface between 755 and $810 \mathrm{~m}$ of altitude with slope ranging between 0 and $24 \%$, and scattered groups located at south-east and south-west from the area with highest numbers of adult trees sited northward (Fig. 2). The sex ratio recorded is 43.67 (percentage of females). Descriptive analysis revealed as Taxus baccata covers an area of 25 ha (sum of cells $20 \times 20 \mathrm{~m}$ with established trees, ET) over 341 ha (total amount of cells within the study

Table 1. Demographic attributes of study area at Foresta Umbra obtained by the total census of adult yew trees and regeneration summarized on $20 \times 20$ m grid cells

\begin{tabular}{|c|c|}
\hline \multicolumn{2}{|c|}{ Demographic and spatial attributes } \\
\hline Overall area (ha) & 341 \\
\hline ET population surface (ha) & 25 \\
\hline Overall ET density (stem/ha) & 3 \\
\hline Overall basal area $\left(\mathrm{m}^{2} / \mathrm{ha}\right)$ & 1.16 \\
\hline Mean cell ET density (stem/ha) & 41 \\
\hline Mean cell basal area $\left(\mathrm{m}^{2} / \mathrm{ha}\right)$ & 15.78 \\
\hline Overall regeneration density (N/ha) & 17 \\
\hline Regeneration density (N/ha) & 392 \\
\hline NNOMD $\left(B A<10 \mathrm{~m}^{2} / \mathrm{ha} ; \mathrm{m}\right)$ & 42.63 \\
\hline $\operatorname{NNOMD}\left(10 \leq \mathrm{BA} \leq 30 \mathrm{~m}^{2} / \mathrm{ha} ; \mathrm{m}\right)$ & 35.37 \\
\hline NNOMD (BA > 30 m²/ha; m) & 52.36 \\
\hline NNOMD (A1) & 26.5 \\
\hline NNOMD (A2) & 31.75 \\
\hline NNOMD (A3) & 26.54 \\
\hline Number of established trees (ET) & 1024 \\
\hline Number of female $(F)$ & 321 \\
\hline Number of male $(\mathrm{M})$ & 414 \\
\hline Number of undeterminated (U) & 288 \\
\hline Number of monoecious (MF) & 1 \\
\hline Sex ratio (\% females) & 43.67 \\
\hline Mean diameter $(\mathrm{cm}) \pm \mathrm{SD}$ & $55.48 \pm 42.9$ \\
\hline Mean height $(\mathrm{cm}) \pm \mathrm{SD}$ & $10.19 \pm 5.9$ \\
\hline
\end{tabular}

Note: Overall population density and basal area were computed considering all cells (including those without yew) inside the perimeter occupied by the yew population (see Materials and methods). Mean cell density and mean cell basal area were computed using only grid cells containing yew trees (trees: $\mathrm{DBH}>3 \mathrm{~cm}$ ); NNOMD $=$ Nearest Neighbor Observed Mean Distance.
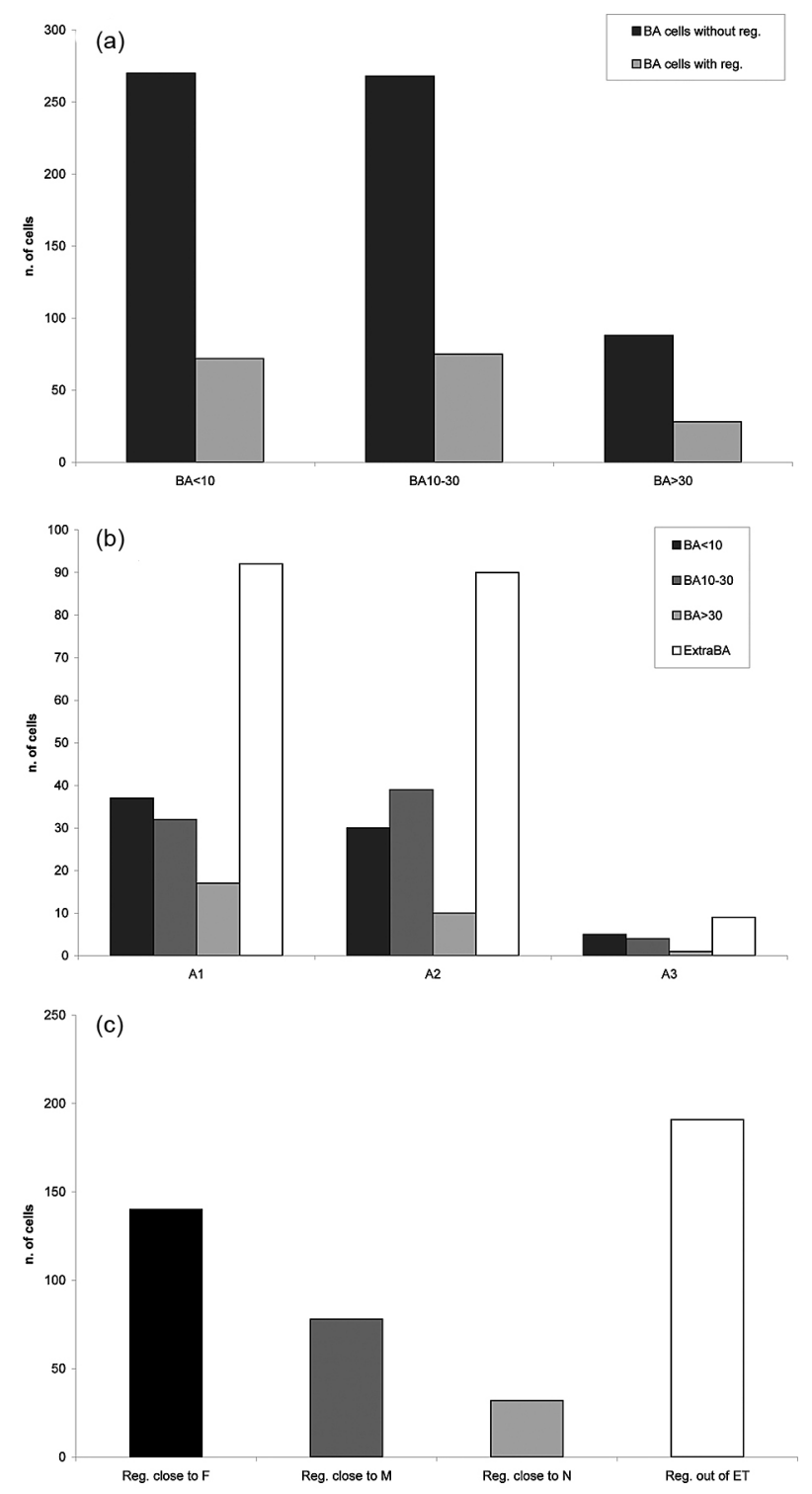

Fig. 3. Quantitative histogram of yew basal area cells at Foresta Umbra with and without regeneration presence (a), distribution of regeneration abundance classes (A1, A2 and A3), in terms of number of cells, related to basal area classes of yew ET (b), and number of regeneration cells close to adult yew trees (c) grouped by sex (female $=\mathrm{F}$; male $=\mathrm{M}$; undetermined $=\mathrm{U}$ ), as result of intersect function computed in ArcMap and setting the affected radius of each ET at $5 \mathrm{~m}$ (see Materials and methods)

area), with an overall ET density of 3 stems/ha and an overall basal area of $1.16 \mathrm{~m}^{2} /$ ha (Table 1 ).

Data recorded from the entire area showed that regeneration is mainly out of the cells with ET. Nevertheless, the regeneration is probably almost of gamic origin, because of relatively close to female adult trees (Figs. 3 and 4 ).

Magini index values and regeneration abundance of yew, recorded on 8 out of 12 circular plots show significant negative correlations with mean DBH and 


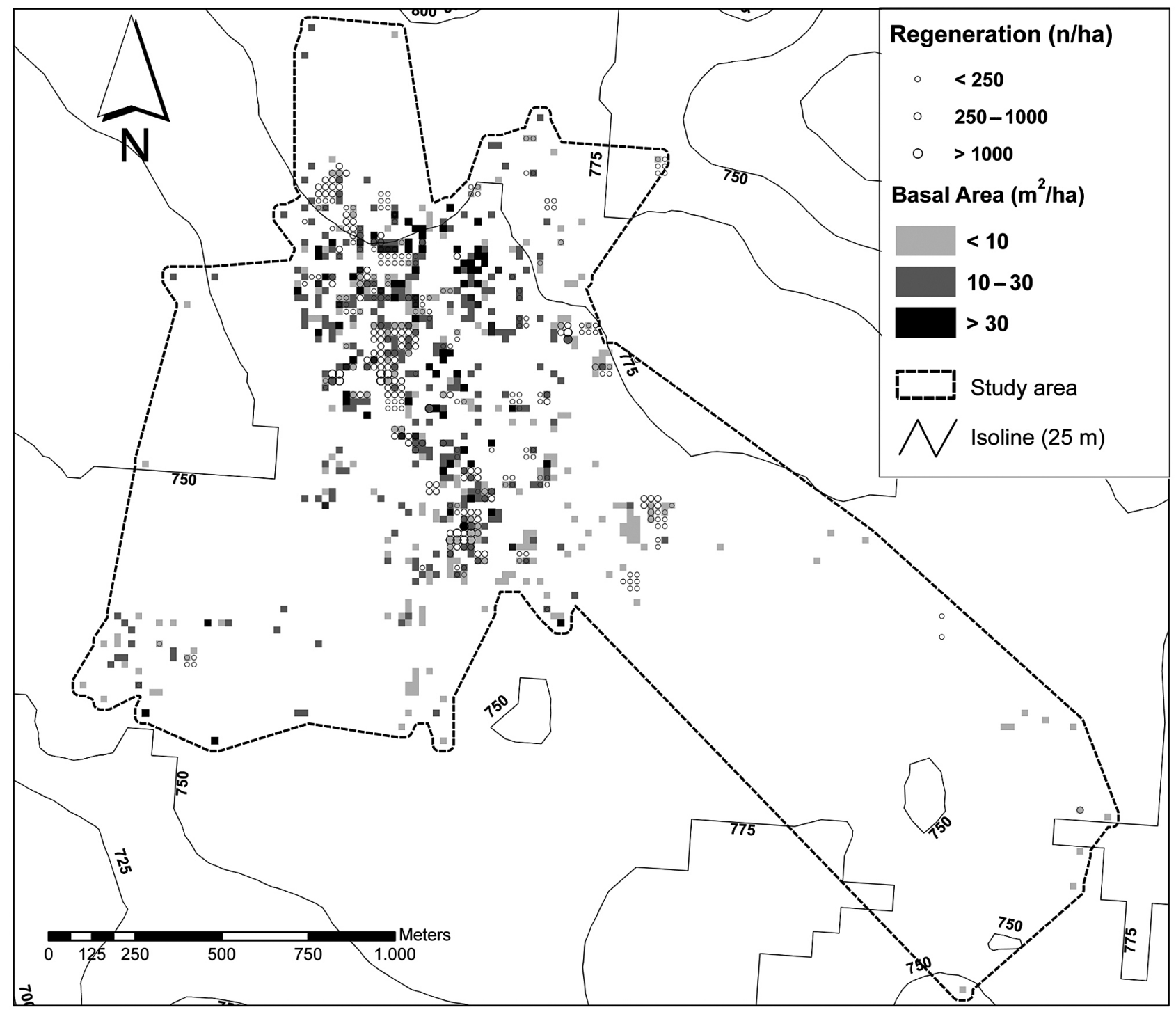

Fig. 4. Census map of yew population at Foresta Umbra. Basal area and regeneration abundance were computed by data collected on $20 \times 20$ grid cells

height of beech and hornbeam ( $\mathrm{r}_{\mathrm{s}}$ between -0.69 and -0.78 ; cf. Table 2 for details), stating that a strong shadiness by overstorey species affected yew affirmation.

Relationships with topographic parameters, collected from circular plots, showed a preference of cool exposures (North and East) for a better regeneration success $\left(\chi^{2}=32.22 ; \mathrm{df}=8 ; \mathrm{p}<0.01\right)$. Slopes less than $10 \%$ also influence regeneration distribution $\left(\chi^{2}=15.76 ; \mathrm{df}=2 ; \mathrm{p}<0.01\right)$, and correlation with rockiness revealed a high significant value between abundance and slopes ranging from 10 to 20 $\%\left(\chi^{2}=34.94 ; \mathrm{df}=2 ; \mathrm{p}<0.01\right)$ (Table 2).

Other parameters considered in this study did not correlate significantly to regeneration abundance and growth (Table 2).

Established yew trees grouped by sex showed different directional distributions, as confirmed by standard deviational ellipses (Fig. 5a); main orien- tations of females and undetermined plants, corresponding to the major axis of the ellipses, are NWSE oriented with a distance between mean centers equal to $168 \mathrm{~m}$. Besides, male distributional trend is not so stretched along a spatial direction; in fact, males' ellipse is approximated to a circle, and its mean centre is $230 \mathrm{~m}$ from the undetermined one. This could be evaluated as a major "staticity" of male individuals compared to the females, which follow a trend similar to the undetermined trees (i.e. the youngest yew generations). Regeneration occurrence also showed a directional trend, as females and undetermined, but its ellipse is more overlapped, i.e. spatially linked to the presence of male and female adult trees.

Kernel density magnitudes, evaluated for sex classes, showed hotspots where yews of a specific sex class are concentrated, according to five intensity classes, thus partially explaining the distribution- 
Table 2. Dendrometric and environmental attributes with regeneration pattern in 12 randomly located circular plots with a $15 \mathrm{~m}$ radius at Foresta Umbra, with results of statistic tests using Spearman rank correlation coefficient $\left(\mathrm{r}_{\mathrm{s}}\right)$ and $\chi^{2}$

\begin{tabular}{|c|c|c|c|c|c|c|c|c|c|c|c|c|c|c|}
\hline Plots & $\begin{array}{l}\text { Reg. ab. } \\
\text { (N/ha) }\end{array}$ & Ir & $\begin{array}{l}\text { N/ha } \\
\text { F.s. }\end{array}$ & $\begin{array}{l}\text { N/ha } \\
\text { C.b. }\end{array}$ & $\begin{array}{l}\text { G/ha } \\
\text { F. s. }\end{array}$ & $\begin{array}{l}\text { G/ha } \\
\text { C.b. }\end{array}$ & $\begin{array}{c}\text { Gtot/ } \\
\text { ha }\end{array}$ & \multicolumn{2}{|c|}{$\begin{array}{c}\text { Density } \\
\text { (stems/ha) }\end{array}$} & $\begin{array}{c}\text { Mean } \\
\text { DBH } \\
(\mathrm{cm})\end{array}$ & $\begin{array}{c}\text { Mean } \\
\text { height } \\
(\mathrm{m})\end{array}$ & A & $\begin{array}{c}S \\
(\%)\end{array}$ & $\begin{array}{c}\mathrm{R} \\
(\%)\end{array}$ \\
\hline 1 & 99 & 32.5 & 410 & 212 & 26.4 & 6 & 40 & \multicolumn{2}{|c|}{1485} & 19 & 17 & $S$ & 15 & 0 \\
\hline 2 & 453 & 238 & 184 & 240 & 18.9 & 5.13 & 27 & \multicolumn{2}{|c|}{1188} & 17 & 16 & $\mathrm{E}$ & 20 & 2 \\
\hline 3 & 495 & 232 & 849 & 325 & 24.1 & 5.94 & 33 & \multicolumn{2}{|c|}{1344} & 18 & 15 & $\mathrm{~N}$ & 2.6 & 15 \\
\hline 4 & 141 & 38 & 580 & 354 & 9.84 & 9.43 & 41 & \multicolumn{2}{|c|}{1117} & 22 & 17 & - & 3.5 & 0 \\
\hline 5 & 933 & 298 & 622 & 891 & 19.03 & 18.25 & 39 & \multicolumn{2}{|c|}{1627} & 17 & 15 & $\mathrm{~N}$ & 0.9 & 20 \\
\hline 6 & 141 & 71 & 184 & 552 & 9.69 & 6.12 & 51 & \multicolumn{2}{|c|}{1612} & 20 & 15 & W & 16 & 40 \\
\hline 7 & 453 & 275 & 113 & 665 & 6.67 & 10.58 & 23 & \multicolumn{2}{|c|}{863} & 19 & 15 & $\mathrm{E}$ & 10.5 & 10 \\
\hline 8 & 141 & 58 & 240 & 481 & 4.66 & 18.36 & 24 & \multicolumn{2}{|c|}{764} & 20 & 17 & $\mathrm{~N}$ & 21 & 0 \\
\hline 9 & - & - & 212 & 354 & 22.83 & 6.71 & 43 & \multicolumn{2}{|c|}{1061} & 23 & 14 & S-E & 7 & 30 \\
\hline 10 & - & - & 368 & - & 16.27 & - & 33 & \multicolumn{2}{|c|}{1061} & 20 & 15 & S-E & 33.5 & 90 \\
\hline 11 & - & - & 28 & 523 & 3.55 & 19.23 & 32 & \multicolumn{2}{|c|}{1018} & 20 & 14 & W & 15 & 70 \\
\hline 12 & - & - & - & 14 & - & 1.02 & 34 & \multicolumn{2}{|c|}{2221} & 14 & 11 & - & 36.4 & 95 \\
\hline \multicolumn{5}{|c|}{ Correlation } & $\mathrm{r}_{\mathrm{s}}$ & \multicolumn{2}{|c|}{$\mathrm{p}$ value } & $\chi^{2}$ & d.f & & & & & \\
\hline \multicolumn{5}{|c|}{ Ir vs G/ha F.s. } & -0.09 & \multicolumn{2}{|c|}{$\mathrm{ns}$} & & & & & & & \\
\hline \multicolumn{5}{|c|}{ Ir vs $\mathrm{G} / \mathrm{ha}$ C.b. } & 0.12 & \multicolumn{2}{|c|}{ ns } & & & & & & & \\
\hline \multicolumn{4}{|c|}{ Ir vs Gtot/ha } & & -0.45 & \multicolumn{2}{|c|}{ ns } & & & & & & & \\
\hline \multicolumn{4}{|c|}{ Ir vs Density } & & 0.19 & \multicolumn{2}{|c|}{ ns } & & & & & & & \\
\hline \multicolumn{4}{|c|}{ Ir vs mean $\mathrm{DBH}$} & & -0.69 & \multicolumn{2}{|c|}{$*$} & & & & & & & \\
\hline \multicolumn{4}{|c|}{ Ir vs mean height } & & -0.78 & \multicolumn{2}{|c|}{$*$} & & & & & & & \\
\hline \multicolumn{4}{|c|}{ Ir vs N/ha F.s. } & & -0.12 & & ns & & & & & & & \\
\hline Ir vs $\mathrm{N} / \mathrm{l}$ & a C.b. & & & & 0.62 & & ns & & & & & & & \\
\hline Ir vs $(\mathrm{N})$ & a F.s. $+\mathrm{N}$ & ha C.b.) & & & 0.40 & & ns & & & & & & & \\
\hline Ir vs A & & & & & & & $* *$ & 32.2 & 8 & & & & & \\
\hline Ir vs $S$ & & & & & & & $* *$ & 15.8 & 2 & & & & & \\
\hline Ir vs $\mathrm{R}$ & & & & & & & $* *$ & 34.9 & 2 & & & & & \\
\hline Reg. ab. & s mean Dl & & & & -0.71 & & * & & & & & & & \\
\hline Reg. ab. & s mean he & & & & -0.72 & & $*$ & & & & & & & \\
\hline
\end{tabular}

Note: regeneration abundance (Reg.ab.) summarizes saplings and seedlings of yew; Ir = Magini regeneration index; N/ha F.s. = number of plants per hectare of Fagus sylvatica; N/ha C.b. = number of plants per hectare of Carpinus betulus; G/ha F.s. = basal area of Fagus sylvatica; G/ha C.b. = basal area of Carpinus betulus; Gtot/ha = total basal area per hectare (beech, European hornbeam, and secondary species like Acer spp., chequers tree, manna ash, holm oak, European hop-hornbeam); Density = number of all species' stems per hectare; Mean $\mathrm{DBH}$ and height also refers to all species recorded; $\mathrm{A}=$ exposure; $\mathrm{S}=$ slope in percentage; $\mathrm{R}=$ rockiness in percentage. Significant codes: *** $(\mathrm{P}<0.001)$;* $^{* *}(0.01)$; $^{*}(0.05)$; ns (not significant).

al trend computed by standard deviational ellipses (Fig. 5b, c, d). This is particularly evident for undetermined plants, with most dense nucleus (class 5 $=16.67-20.82 \mathrm{~N} / \mathrm{ha}$ ) occurring at south-east from the "core" of the entire population (black circle line) characterized by highest yew basal area. Moreover, thick male groups are at higher altitude than female ones, and only partially overlapped with them.

Mean DBH spatial variation showed how adult yew trees tend to decrease quickly in the north-eastern side of the area, where occurrence of beech and hornbeam is more intense, while in the remaining site the DBH reduction is more gradual. Separating males and females in two sub-sets, more detailed behaviors are detectable (Fig. 6a, c): in the upper side of the area, males are represented by higher values of mean DBH than females (60-90 cm for males; 40$80 \mathrm{~cm}$ for females); in the population core, surfaces with highest values are not overlapped except for a minimum size; there is a large surface from the core to the south-west side where females mean DBH is around $70 \mathrm{~cm}$, while males decrease from $80 \mathrm{~cm}$ to $50 \mathrm{~cm}$.

The model is confirmed by basal area variation maps: males are distributed from the core area with a regular centrifugal model, while females seem to be centered on well detectable zones (Fig. 6b, d).

Spatial attributes for ET have also been evaluated from basal area, computed from $20 \times 20$ m grid cells and reported in Table 1. Mean distance of the centers of the cells belonging to the same basal area class was $42.63 \mathrm{~m}$ for class 1 (BA $\left.<10 \mathrm{~m}^{2} / \mathrm{ha}\right), 35.37 \mathrm{~m}$ for class $2\left(10 \leq \mathrm{BA} \leq 30 \mathrm{~m}^{2} / \mathrm{ha}\right)$ and 52.36 for class $3\left(\mathrm{BA}>30 \mathrm{~m}^{2} / \mathrm{ha}\right)$. Therefore, the cells with intermediate basal area resulted less widespread than the ones belonging to the other two classes.

Also regeneration abundance was spatially described by computing the nearest neighbor observed mean distance, and results showed closest values for abundance A1 ( $<250$ plants/ha) and A3 ( $>$ 

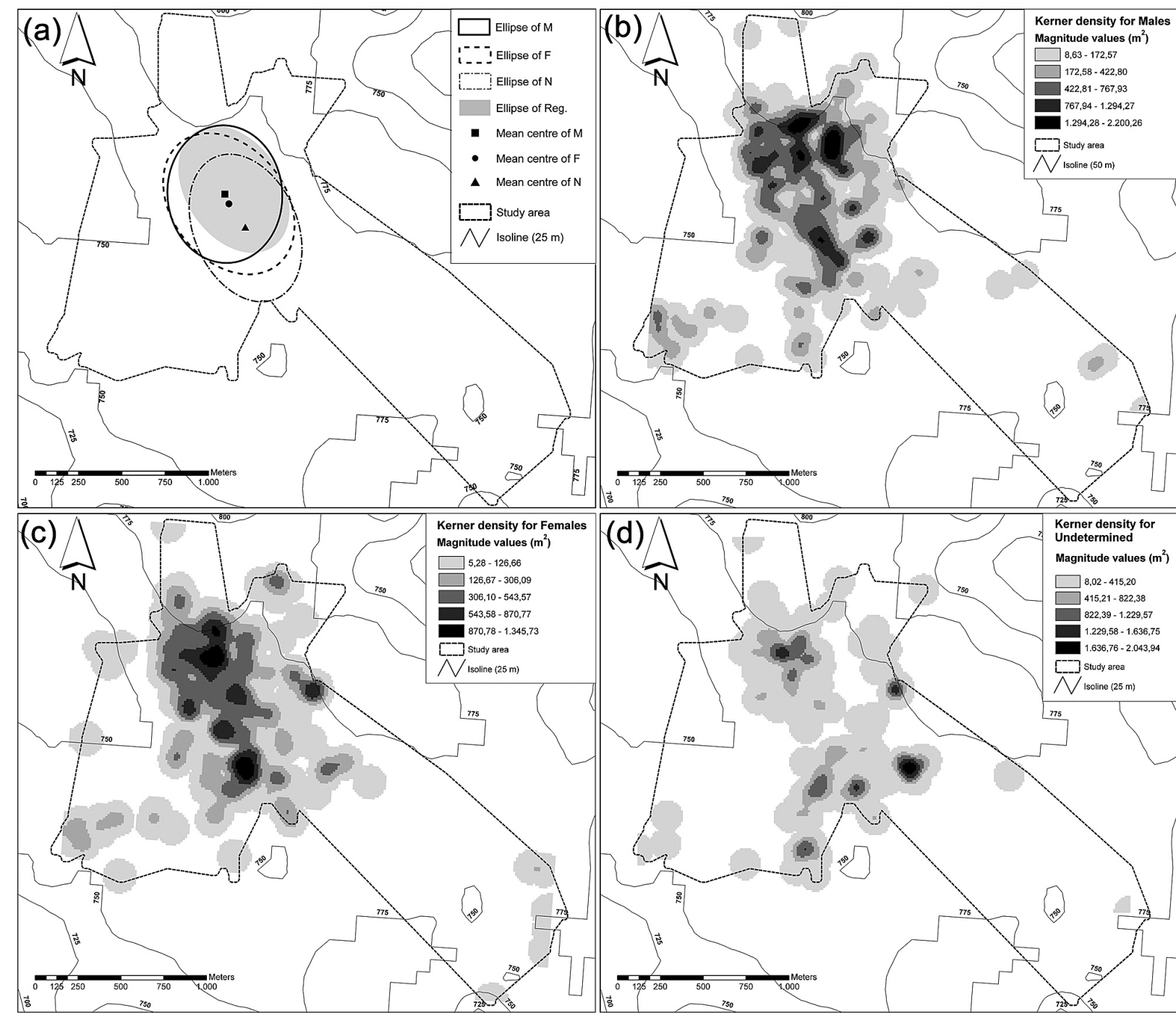

Fig. 5. Spatial patterns of yew distribution by sex and regeneration abundance. Directional distribution calculated for each sex class and regeneration using standard deviational ellipse (a); approximate Gaussian kernel density of sex classes and magnitude estimation as number of ET occurrence per hectare (b,c,d)

1000 plants/ha), while the intermediate class A2 resulted to be a bit more widespread than the previous one (26.5 m c.a. for A1 and A3 vs 31.75 for A2, see Table 1).

For variogram analysis, the nugget plus exponential model was usually chosen to represent spatial continuity of yew basal area and regeneration abundance (Fig. 7a, b), based on the $\mathrm{R}^{2}$ values of the models fit to the sample omni-directional variograms (Table 3). The amount of spatial dependence (SPD) indicated by variogram models was greater for regeneration than for basal area, suggesting that regeneration has occurred with large spatial homogeneity (99.7\% vs $90 \%)$. This evidence is confirmed by the similarity between regeneration abundance classes that extends over longer distance than basal area (155 m vs $88 \mathrm{~m}$ ).

Sample cross-variogram between yew BA and regeneration (Fig. 7c) was best fit by a Gaussian mod- el, and inverse spatial co-dependence was found, with SPD $=99.8 \%$ and range set up to $89 \mathrm{~m}$. Both variogram and cross-variogram analysis also showed a nugget-sill ratio closed to zero, thus random variation at the scale level considered is almost absent and spatial dependence should be considered very strong.

Table 3. Variograms and cross-variogram parameters of best-fitting estimated models for basal area and regeneration abundance at Foresta Umbra. SPD $=$ Spatial dependence; $\mathrm{BA}=$ basal area; Reg.ab. = Regeneration abundance

\begin{tabular}{lcccccc}
\hline \multicolumn{1}{c}{ Variable } & Model & Nugget & Sill & $\begin{array}{c}\text { Range } \\
(\mathrm{m})\end{array}$ & $\begin{array}{c}\text { SPD } \\
(\%)\end{array}$ & $\mathrm{R}^{2}$ \\
\hline BA & Exponential & 0.51 & 4.83 & 88 & 90 & 0.69 \\
Reg.ab & Exponential & 0.001 & 0.35 & 155 & 99.7 & 0.88 \\
BA-Reg.ab. & Gaussian & -0.001 & -0.51 & 89 & 99.8 & 0.91 \\
\hline
\end{tabular}



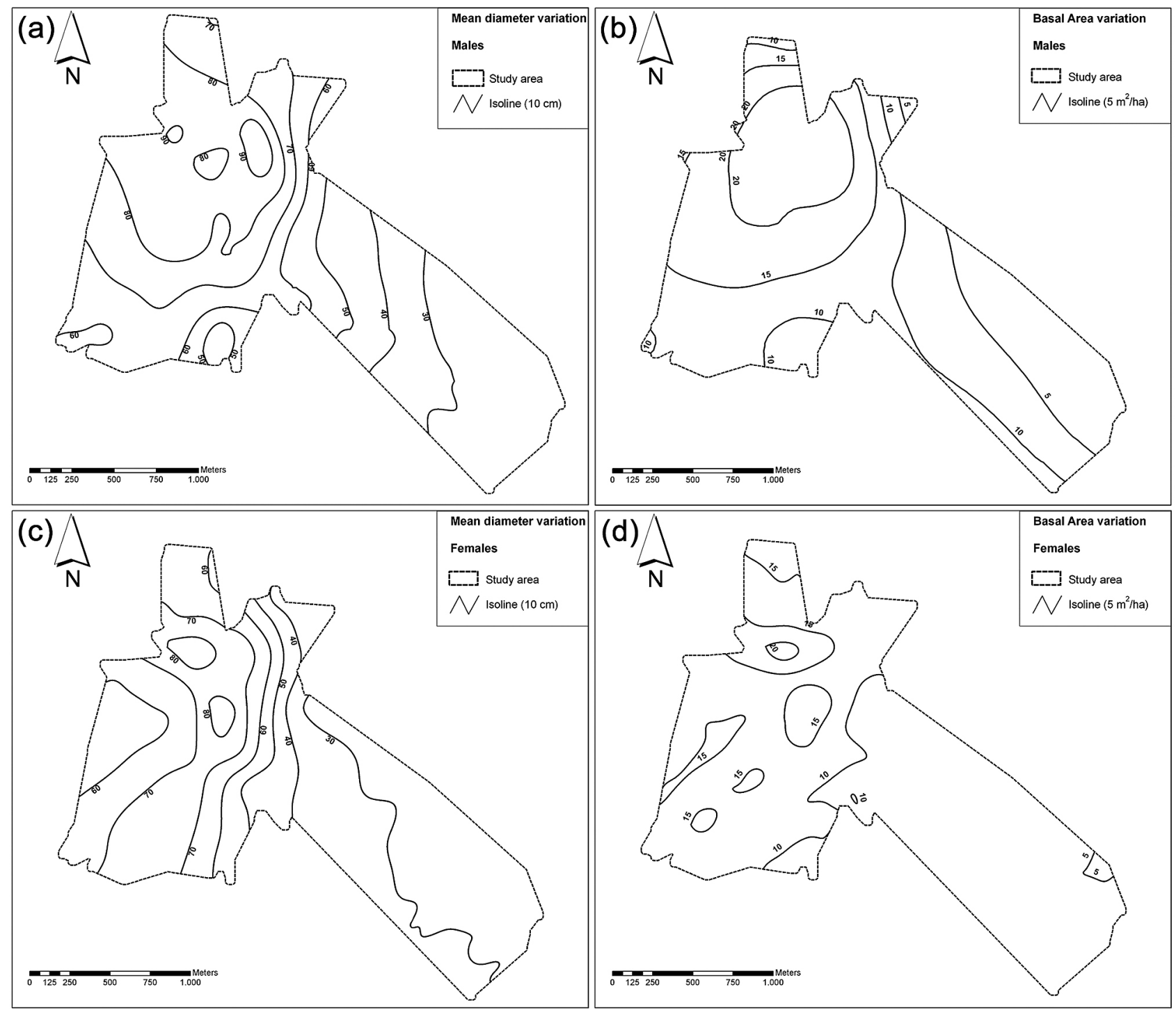

Fig. 6. Spatial variation of mean DBH and basal area for males (a, b) and females (c, d) using local polynomial intersection function

\section{Discussion}

The sex ratio calculated at Foresta Umbra well fits with other yew populations along Europe, as summarized by Iszkuło et al. (2009) and Hilfiker et al. (2004). At the same time, the higher percentage of recorded males might be explained by the old-growth status of Foresta Umbra (cf. Bañuelos and Obeso 2004) or by the Mediterranean climate regime, generally less permissive for the species than northern ones (cf. Klinkhamer and de Jong 1997; Gauquelin et al. 2002).

Compared to other Italian or Greek yew stands (Piovesan et al. 2009; Katsavou and Ganatsas 2012), Foresta Umbra is characterized by yew low stem density per hectare, but remarkable basal area and diameter (for a comparison see also Rikhari et al. 1998). Yew distribution is spatially heterogeneous with isolated individuals or dense segregated groups; the occurrence of largest individuals belonging to the overstorey, as well as old yew trees, leads to strong inter- and intra-specific competition. Data recorded from the entire site showed that regeneration distribution is mainly located in small areas with better micro-environmental condition (e.g. holes where shading by overstorey species is not excessive), thus avoiding direct competition with adult yews, as observed by De Angelis (2004) and Piovesan et al. (2009) in Central Italy. This might be also explained with the inhibition of seed germination by the emission of allelopathic substances from root system area (Iszkuło and Boratyński 2004), as observed in Taxus brevifolia (del Moral and Cates 1971; Rice 1974), Juglans nigra and Juglans regia (Massey 1925; Bode 1958). Where gamic regeneration successes under yew established trees, it takes place close to mother tree crowns, as effect of seed dispersal by gravity and zoochory. However, this occurrence is limited if com- 

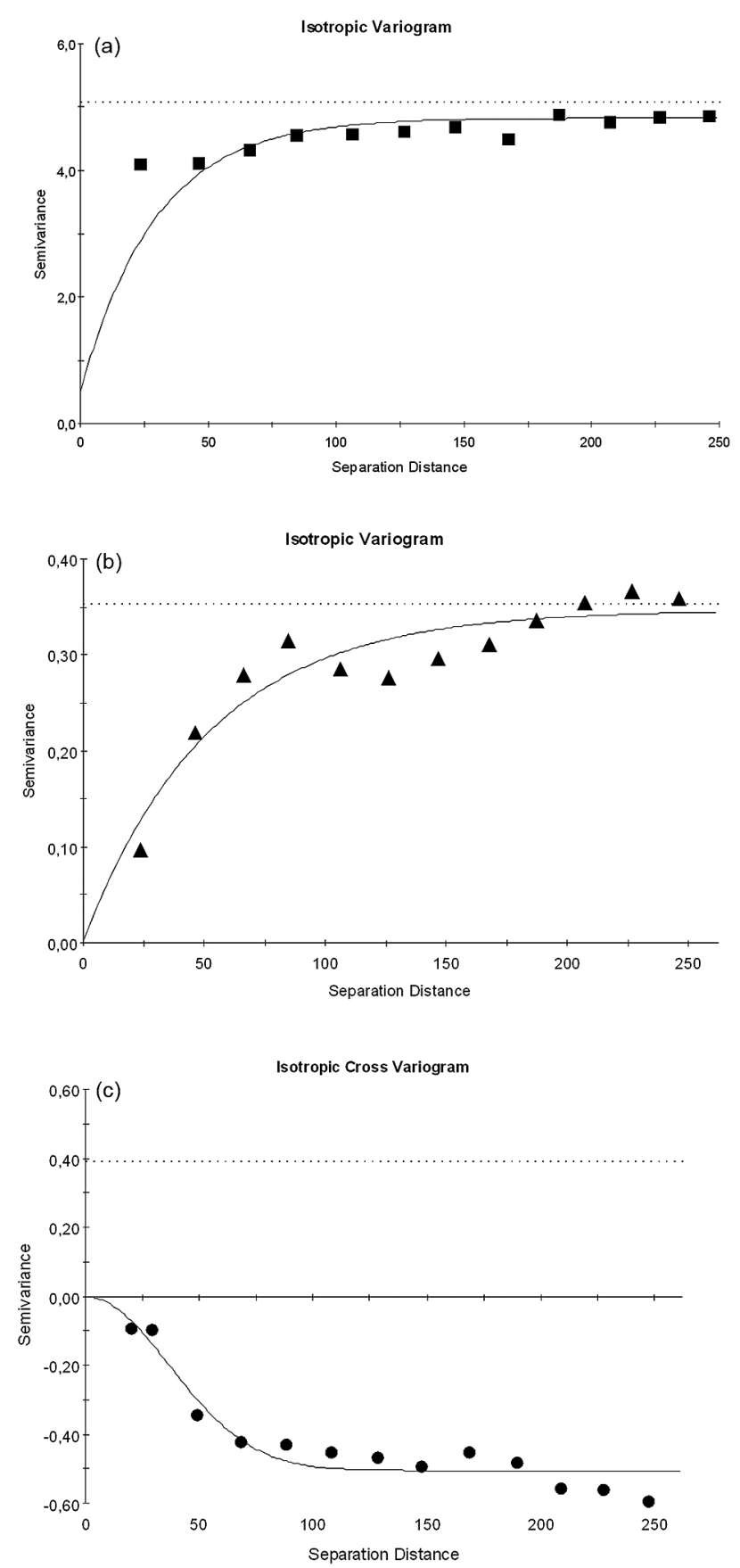

Fig. 7. Variograms computed from total census data of the yew population at Foresta Umbra. Sample variograms $(\mathrm{a}, \mathrm{b})$ for basal area (filled squares) and regeneration (filled triangles) and model fit (line). Cross-variogram (c) between basal area and regeneration abundance (filled circles) and model fit (line)

pared to the one outside the canopy of old yew trees (Iszkuło and Boratyński 2004).

The forest structure shows the relevance of established trees (beech, hornbeam and yew) in spatially yew regeneration processes. The influence of the forest structure on the regeneration abundance is confirmed by Magini index value and it is highlighted by the negative correlation with overstorey species' size as found in Denmark by Svenning and Magård (1999), and in Poland by Giertych (2000).

Geostatistical analyses revealed that occurring patches of established yews are wide enough to influence regeneration abundance, as observed at Tassiti (Central Apennines) by Piovesan et al. (2009); the only difference regards the patches' dimension (88 $\mathrm{m}$ at Foresta Umbra, $63 \mathrm{~m}$ at Tassiti). Regeneration abundance size range also evidenced similarities with Tassiti core group, but at Foresta Umbra it reaches higher value, stating a homogeneity not observed in the Apennine ( $155 \mathrm{~m}$ vs. $50-106 \mathrm{~m}$ ). Overall, the autocorrelation structure observed at Foresta Umbra is similar to the Abruzzi yew stands of Femmina Morta and Tassiti core group. Combining variogram and cross-variogram models it is possible to point out an inverse relationship between yew basal area and regeneration at local scale. As established yew trees density increased, regeneration dropped, confirming the results of Piovesan et al. (2009) for Tassiti and Femmina Morta. This phenomenon is clear in well-structured old forests, with spatially homogeneous dense groups and/or large individuals, in particular at short distances (tens of meters). A similar process was not observed in Greece, where present stand status does not represent the conditions where yew individuals were established (Katsavou and Ganatsas 2012), but it has been pointed out for yew forests of Central Europe (Hulme 1996; Dovciak 2002), in holly (Ilex aquifolium L.) populations (Arrieta and Suarez 2006), and it is like the phenomenon of reciprocal replacement found in mixed European beech-silver fir forests (Dobrowolska 1998). Considering yew requirements in terms of light availability, in particular when it reaches the sapling stage (Iszkuło and Boratyński 2006), Taxus baccata "woods" might be dynamically related to the senescent phase of beech forests (Peterken 1996), which favours overstorey gaps formation useful to yew saplings exploitation (Hageneder 2007; Piovesan et al. 2009; Katsavou and Ganatsas 2012).

Comparison of our results with yew stands in the Apennines (Di Cosmo 2003; De Angelis 2004; Piovesan et al. 2009), in Greece (Katsavou and Ganatsas 2012) and other published literature (Rikhari et al. 1998; Dovciak 2002; García and Obeso 2003; Kwit et al. 2004; Perrin et al. 2006), indicates that the average density of seedling at Foresta Umbra can be described as low. This lack of regeneration may be also due to the senescence of many adult yew trees, thus to limited pollination and/or seed production, even if such incidence has not been accurately evaluated yet. Herbivores can affect yew regeneration too, negatively impacting the intermediate height class of saplings, as stated in Central Apennines (Piovesan et al. 2009), in other Mediterranean forests (Farris 
and Filigheddu 2008; Sanz et al. 2009) and Central Europe (Tittensor 1980; Ammer 1996; Thomas and Polwart 2003; Dhar et al. 2007; Iszkuło et al. 2014), even if at Foresta Umbra grazing is under adequate control.

Although Taxus baccata is considered a shade-tolerant species, regeneration is favored by an open canopy (Svenning and Magård 1999; Insinna and Ammer 2000). However, beech forests with yew in peninsular Italy are bioclimatically different from the European ones (Piovesan et al. 2005): reducing shading of the ground may lead to hardwood or grass regeneration more than yew (Iszkuło and Boratyński 2006), and higher level of evapotranspiration during warmer period when drought stress occurs. On the other side, productions of yew cones is strongly affected by dense beech canopy, and Foresta Umbra matches with observations of other authors (Watt 1926; Hulme 1996).

About slope, regeneration distribution and abundance are mainly linked to the first class (slope < $10 \%$ ), probably because of females position on flat and favourable sites, as well as seed dispersal dynamics that tend to store seeds at lower slopes. Moreover, under warmer climate, gentler slope angles allow for reduced drought stress through greater persistence of snow pack and soil moisture, as stated for Central Italy (Piovesan et al. 2009). Correlation with rockiness revealed strong competition ability of yew seedlings with other species on microsites where soil deepness is a growing limiting factor; the species is supported by a strong root system, useful to vegetate on rocky sites, as often observed also for adult trees, then allowing to fill a peculiar ecological niche with sufficient light availability.

Spatial relationship for sex ratio on altitude at local scale has been observed with males $50 \mathrm{~m}$ higher than females. Such distribution is not accidental, but clarifies regeneration dynamism as described by the directional ellipses showed in Fig. 5a. As many authors confirmed (Iglesias and Bell 1989; Dawson and Ehleringer 1993; Eppley et al. 1998; Ortiz et al. 1998; Bertaudiere et al. 2001; Hultine et al. 2007), most of dioecious species reflect sex spatial segregation related to different microhabitats. In particular, for several species, sexes are distributed such that females occur in higher-resources microsites than males. This segregation is strongly linked to the different reproductive efforts, i.e. females use to require more resources in terms of water, nitrogen, etc. than males, and it is typical of dioecious wind-pollinated species (Bierzychudek and Eckhart 1988; Freeman et al. 1997). At Foresta Umbra female yew trees are at lower altitude, mainly in flat areas or folds where water stagnation and nutrients storage by microerosion make plant growth more performing, thus aiding females' spatial segregation and regeneration distribution.
Regeneration is abundant at S and SE parts of the study site, under suitable conditions where also female trees are striking oriented. Basal area gradient distribution states the effectiveness of males to spread and colonize new sites even under critical ecological conditions; on the other hand, females are clustered around ecologically favourable areas.

In conclusion, these features are further assessments that Taxus baccata has a flexible behaviour, acting both as a pioneer and a climax species (Leuthold 1998; Hageneder 2007). Regeneration success and its spatial distribution were demonstrated once again to be strictly linked to forest density and structure (cf. Linares 2013). This issue critically arises in oldgrowth forests, where inter- intra-specific competitions are strong and spatial availability for the new generations are often scarce.

A deeper understanding of the adaptive effectiveness of yew in Mediterranean environment could help to improve management protocols for ensuring the conservation of existing populations, and for encouraging the species' resilience into areas where yew is endangered.

\section{Acknowledgements}

We would like to thank the Regional Forest Directorate of Apulia for conceding the logistic support during the work. We are particularly indebted to Dr. Alfredo Alessandrini for providing useful data for comparisons, to Prof. Jonathan Adams of Department of Biological Sciences, Seoul National University, and Prof. Luca Santi of D.A.F.N.E. Department, University of Tuscia, for the scientific and linguistic supervision of the whole paper.

\section{References}

Ammer C. 1996. Impact of ungulates on structure and dynamics of natural regeneration of mixed mountain forests in the Bavarian Alps. Forest Ecology and Management 88: 43-45.

Arista M., Ortiz P.L., Talavera S. 1997. Reproductive isolation of two sympatric subspecies of Juniperus phoenicea (Cupressaceae) in southern Spain. Plant Systematics and Evolution 208: 225-237.

Arrieta S., Suarez F. 2006. Marginal holly (Ilex aquifolium L.) populations in Mediterranean central Spain are constrained by a low-seedling recruitment. Flora 201: 152-160.

Bacchetta G., Farris E. 2006. Studio fitosociologico, ecologico e corologico di Taxus baccata in Sardegna (Italia). In: El tejo en el Mediterráneo occidental: Jornadas Internacionales sobre el tejo y las tejeras en el Mediterráneo occidental. Conselleria de Territori i Habitatge, pp. 195-204. 
Baldoni M., Biondi E., Ferrante L. 2004. Demographic and spatial analysis of a population of Juniperus oxycedrus L. in an abandoned grassland. Plant Biosystems 138: 89-100.

Bañuelos M.J., Obeso J.R. 2004. Resource allocation in the dioecious shrub Rhamnus alpinus: the hidden costs of reproduction. Evolutionary Ecology Research 6: 397-413.

Bertaudiere V., Montes N., Badri W., Gauquelin T. 2001. Multicaulis structure of Juniperus thurifera: adaptation to a severe environment? Comptes Rendus De L Academie Des Sciences Serie Iii-Sciences De La Vie-Life Sciences III-Vie 324: 627-634.

Bierzychudek P., Eckhart V. 1988. Spatial segregation of the sexes of dioecious plants. American Naturalist 132: 34-43.

Bode H.R. 1958. Beiträge zur Kenntnis Allelopapathischer Erscheinungen bei einigen Juglandaceen. Planta 51: 440-480.

Boratyński A., Kmiecik M., Kosiński P., Kwiatkowski P., Szczęśniak E. 1997. Protected and deserving protection trees and shrubs of the Polish Sudety Mts. with their prealps. Taxus baccata L. Arboretum Kórnickie 42: 111-147.

Brullo S., Minissale P., Signorello P., Spampinato. G. 1996. Contributo alla conoscenza della vegetazione forestale della Sicilia. Colloques Phytosociologiques 24: 635-647.

Brullo S., Scelsi F., Spampinato G. 2001. La vegetazione dell'Aspromonte. Studio fitosociologico. Laruffa, Reggio Calabria.

Bugala W. 1978. Systematics and variability. In: The yew - Taxus baccata L. Bialobok S. (ed.). Foreign Scientific Publications Department of the National Center for Scientific, Technical, and Economic Information, (for the Department of Agriculture and the National Science Foundation, Washington D.C.), Warsaw, pp. 15-32.

Cedro A., Iszkuło G. 2011. Do females differ from males of European yew (Taxus baccata L.) in dendrochronological analysis? Tree-Ring Research 67: 3-11.

Cipollini M.L., Stiles E.W. 1991. Costs of Reproduction in Nyssa sylvatica - Sexual Dimorphism in Reproductive Frequency and Nutrient Flux. Oecologia 86: 585-593.

Dawson T.E., Ehleringer J.R. 1993. Gender-Specific Physiology, Carbon Isotope Discrimination, and Habitat Distribution in Boxelder, Acer negundo. Ecology 74: 798-815.

De Angelis A. 2004. Ecologia e distribuzione del tasso (Taxus baccata L.) in Abruzzo orientale. Graduate degree, Università degli Studi della Tuscia, Viterbo. de Jong T.J., van der Meijden E. 2004. Sex ratio of some long-lived dioecious plants in a sand dune area. Plant Biology 6: 616-620.

del Moral R., Cates R.G. 1971. Allelopathic potential of the dominant vegetation of western Washington. Ecology 52: 1030-1037.

Dhar A., Ruprecht H., Klumpp R., Vacik H. 2007. Comparison of ecological condition and conservation status of English yew population in two Austrian gene conservation forests. Journal of Forestry Research. 18: 181-186.

Di Cosmo L. 2003. Dendroecologia del tasso: un caso di studio. In: Il tasso, un albero da conoscere e conservare. Schirone B., Bellarosa R., Piovesan G. (eds.). Cogecstre, Penne, pp. 85-93.

Dimov L.D., Chambers J.L., Lockhart B.R. 2005. Spatial continuity of tree attributes in bottomland hardwood forests in the southeastern United States. Forest Science 51: 532-540.

Dobrowolska D. 1998. Structure of silver fir (Abies alba Mill.) natural regeneration in the 'Jata' reserve in Poland. Forest Ecology and Management 110: 237-247.

Dovciak M. 2002. Population dynamics of the endangered English yew (Taxus baccata L.) and its management implications for biosphere reserves of the Western Carpathians. In: Young Scientist Award 2002 Research Study. U. MAB Secretariat, Division of Ecological Sciences (ed.). Department of Applied Ecology, Faculty of Ecology and Environmental Sciences, Zvolen Technical University, Banská Štiavnica, Slovakia, pp. 1-43.

Eppley S.M., Stanton M.L., Grosberg R.K. 1998. Intrapopulation sex ratio variation in the salt grass Distichlis spicata. American Naturalist 152: 659670.

Espirito-Santo M.M., Madeira B.G., Neves F.S., Faria M.L., Fagundes M., Fernandes G.W. 2003. Sexual differences in reproductive phenology and their consequences for the demography of Baccharis dracunculifolia (Asteraceae), a dioecious tropical shrub. Annals of Botany 91: 13-19.

Faliński J.B. 1980. Vegetation dynamics and sex structure of the populations of pioneer dioecious woody plants. Vegetatio 43: 23-38.

Faliński J.B. 1998. Dioecious woody pioneer species (Juniperus communis, Populus tremula, Salix s-p. div.) in the secondary succession and regeneration. Phytocoenosis, 8 (N.S.) Seminarium Geobotanicum 10.

Farris E., Filigheddu R. 2008. Effects of browsing in relation to vegetation cover on common yew (Taxus baccata L.) recruitment in Mediterranean environments. Plant Ecology 199: 309-318.

Farris E., Fenu G., Bacchetta G. 2012. Mediterranean Taxus baccata woodlands in Sardinia: a characteri- 
zation of the EU priority habitat 9580. Phytocoenologia 41: 231-246.

Fortin M.J., Dale M.R.T. 2005. Spatial analysis: a guide for ecologists. Cambridge University Press, Cambridge.

Freeman D.C., McArthur E.D., Harper K.T., Blauer A.C. 1981. Influence of environment on the floral sex ratio of monoecious plants. Evolution 35: 194-197.

Freeman D.C., Doust J.L., El-Keblawy A., Miglia K.J. 1997. Sexual specialization and inbreeding avoidance in the evolution of dioecy. Botanical Review 63: 65-92.

Gamma Design Software 2009. GS+ Geostatistics for environmental sciences, version 9. Plainwell, Michigan, USA.

García D., Obeso J.R. 2003. Facilitation by herbivore-mediated nurse plants in a threatened tree, Taxus baccata: Local effects and landscape level consistency. Ecography 26: 739-750.

Gauquelin T., Bertaudiere-Montes V., Badri W., Montes N. 2002. Sex ratio and sexual dimorphism in mountain dioecious thuriferous juniper (Juniperus thurifera L., Cupressaceae). Botanical Journal of the Linnean Society 138: 237-244.

Giertych P. 2000. Factors determining natural regeneration of yew (Taxus baccata L.) in the Kórnik Arboretum. Dendrobiology 45: 31-40.

Givnish T.J. 1980. Ecological constraints on the evolution of breeding systems in seed plants: dioecy and dispersal in gymnosperms. Evolution 34: 959-972.

Hageneder F. 2007. Yew: a history. The History Press Ltd, Sutton Publishing, London.

Hilfiker K., Gugerli F., Schütz J.P., Rotach P., Holderegger R. 2004. Low RAPD variation and female-biased sex ratio indicate genetic drift in small populations of the dioecious conifer Taxus baccata in Switzerland. Conservation Genetics 5: 357-365.

Horwitz S.B. 1992. Mechanism of action of taxol. Trends in Pharmacological Sciences 13: 134-136.

Hulme P.E. 1996. Natural regeneration of yew (Taxus baccata L.): Microsite, seed or herbivore limitation? Journal of Ecology 84: 853-861.

Hultine K.R., Bush S.E., West A.G., Ehleringer J.R. 2007. Population structure, physiology and ecohydrological impacts of dioecious riparian tree species of western North America. Oecologia 154: 85-93.

Iglesias M.C., Bell G. 1989. The small-scale spatial distribution of male and female plants. Oecologia 80: 229-235.

Insinna P., Ammer C. 2000. Investigations of yew (Taxus baccata) in the "Eibenwald bei Paterzell" nature conservation area. Forst und $\mathrm{Holz}$ 55: 136-140.
Iszkuło G. 2010. Success and failure of endangered tree species: Low temperatures and low light availability affect survival and growth of european yew (Taxus baccata L.) seedlings. Polish Journal of Ecology 58: 259-271.

Iszkuło G., Boratyński A. 2004. Interaction between canopy tree species and European yew Taxus baccata (Taxaceae). Polish Journal of Ecology 52: 523-531.

Iszkuło G., Boratyński A. 2005. Different age and spatial structure of two spontaneous subpopulations of Taxus baccata as a result of various intensity of colonization process. Flora 200: 195-206.

Iszkuło G., Boratyński A. 2006. Analysis of the relationship between photosynthetic photon flux density and natural Taxus baccata seedlings occurrence. Acta Oecologica 29: 78-84.

Iszkuło G., Jasińska A.K., Giertych M.J., Boratyński A. 2009. Do secondary sexual dimorphism and female intolerance to drought influence the sex ratio and extinction risk of Taxus baccata? Plant Ecology 200: 229-240.

Iszkuło G., Jasińska A.K., Sobierajska K. 2011. Dendroecological differences between Taxus baccata males and females in comparison with monoecious Abies alba. Dendrobiology 65: 55-61.

Iszkuło G., Didukh Y., Giertych M.J., Jasińska A.K., Sobierajska K., Szmyt J. 2012. Weak competitive ability may explain decline of Taxus baccata. Annals of Forest Science 69: 705-712.

Iszkuło G., Kosiński P., Hajnos M. 2013. Sex influences the taxanes content in Taxus baccata. Acta Physiologiae Plantarum 35: 147-152.

Jahn G. 1991. Temperate deciduous forests of Europe. In: Temperate deciduous forests. Röhrig E., Ulrich B. (eds.). Elsevier, Amsterdam, pp. 377502.

Katsavou I., Ganatsas P. 2012. Ecology and conservation status of Taxus baccata population in NE Chalkidiki, northern Greece. Dendrobiology 68: 55-62.

Klinkhamer P.G.L., de Jong T.J. 1997. Size-dependent sex allocation to male and female reproduction. In: Plant resource allocation. Bazzaz F.A., Grace J. (eds.). Academic Press, London.

Köpp R. 1991. Untersuchungen zur Verjungungsdynamik von Taxus baccata im Naturwaldreservat Eibenwald bei Göttingen. Forstarchiv 62: 188-191.

Krischik V.A., Denno R.F. 1990a. Differences in environmental response between the sexes of the dioecious shrub Baccharis halimifolia (Compositae). Oecologia 83: 176-181.

Krischik V.A., Denno R.F. 1990b. Patterns of growth, reproduction, defense, and herbivory in the dioecious shrub Baccharis halimifolia (Compositae). Oecologia 83: 182-190. 
Katsavou I., Ganatsas P. 2012. Ecology and conservation status of Taxus baccata population in NE Chalkidiki, northern Greece. Dendrobiology 68: $55-62$.

Kwit C., Horvitz C.C., Platt W.J. 2004. Conserving slow-growing, long-lived tree species: Input from the demography of a rare understory conifer, Taxus floridana. Conservation Biology 18: 432-443.

Linares J.C. 2013. Shifting limiting factors for population dynamics and conservation status of the endangered English yew (Taxus baccata L., Taxaceae). Forest Ecology and Management 291: 119-127.

Leuthold C. 1998. Die pflanzensoziologische und ökologische Stellung der Eibe (Taxus baccata L.) in der Schweiz-ein Beitrag zur Wesenscharakterisierung des "Ur-Baumes" Europas. Schweiz Z Forstwes 49: 349-371.

Maestre F.T., Rodriguez F., Bautista S., Cortina J., Bellot J. 2005. Spatial associations and patterns of perennial vegetation in a semi-arid steppe: a multivariate geostatistics approach. Plant Ecology 179: 133-147.

Magini E. 1967. Ricerche sui fattori della rinnovazione naturale dell'abete bianco sull'Appennino. L'Italia Forestale e Montana 22: 261-270.

Magri D., Vendramin G.G., Comps B., Dupanloup I., Geburek T., Gomory D., Latalowa M., Litt T., Paule L., Roure J.M., Tantau I., van der Knaap W.O., Petit R.J., de Beaulieu J.L. 2006. A new scenario for the Quaternary history of European beech populations: palaeobotanical evidence and genetic consequences. New Phytologist 171: 199-221.

Mańka K., Gierczak M., Prusinkiewicz Z. 1968. The succumbing of yew-tree seedlings in Wierzchlas and the saprophytic fungi of the soil environment. Prace Komisji Nauk Rolniczych i Leśnych PTPN 25: 177-195.

Martinis B. 2003. La fragilità del bel paese: geologia dei paesaggi italiani. DEDALO, Bari.

Massei G., Watkins R., Hartley S.E. 2006. Sex-related growth and secondary compounds in Juniperus oxycedrus macrocarpa. Acta Oecologica 29: 135-140.

Massey A.B. 1925. Antagonism of the walnuts (Juglans nigra L. and J. cinerea L.) in certain plant associations. Phytopathology 15: 773-784.

Mendoza I., Zamora R., Castro J. 2009. A seeding experiment for testing tree-community recruitment under variable environments: Implications for forest regeneration and conservation in Mediterranean habitats. Biological Conservation 142: 1491-1499.

Montesinos D., De Luis M., Verdu M., Raventos J., Garcia-Fayos P. 2006. When, how and how much: Gender-specific resource-use strategies in the dioecious tree Juniperus thurifera. Annals of Botany 98: 885-889.
Nicolaou K.C., Dai W.M., Guy R.K. 1994a. Chemistry and biology of taxol. Angewandte Chemie 33: 15-44.

Nicolaou K.C., Yang Z., Liu J.J., Ueno H., Nantermet P.G., Guy R.K., Claiborne C.F., Renaud J., Couladouros E.A., Paulvannan K., Sorensen, E.J. 1994b. Total synthesis of taxol. Nature 367: 630634.

Nuñez C.I., Nuñez M.A., Kitzberger T. 2008. Sex-related spatial segregation and growth in a dioecious conifer along environmental gradients in northwestern Patagonia. Ecoscience 15: 73-80.

Obeso J.R. 2002. The costs of reproduction in plants. New Phytologist 155: 321-348.

Ortiz P.L., Arista M., Talavera S. 1998. Low reproductive success in two subspecies of Juniperus oxycedrus L. International Journal of Plant Sciences 159: 843-847.

Patel P.K., Patel M.A., Chaute B.S. 2009. Antimicrobial activity of various extracts from the leaves of Taxus baccata Linn. (Taxaceae). Pharmacologyonline 2: 217-224.

Perrin P.M., Kelly D.L., Mitchell F.J.G. 2006. Longterm deer exclusion in yew-wood and oakwood habitats in southwest Ireland: Natural regeneration and stand dynamics. Forest Ecology and Management 236: 356-367.

Perrin P.M., Mitchell FJ.G. 2013. Effects of shade on growth, biomass allocation and leaf morphology in European yew (Taxus baccata L.). European Journal of Forest Research 132: 211-218.

Peterken G.F. 1996. Natural woodland: ecology and conservation in northern temperate regions. Cambridge University Press, Cambridge.

Piovesan G., Biondi F., Bernabei M., Di Filippo A., Schirone B. 2005. Spatial and altitudinal bioclimatic zones of the Italian peninsula identified from a beech (Fagus sylvatica L.) tree-ring network. Acta Oecologica 27: 197-210.

Piovesan G., Presutti Saba E., Biondi F., Alessandrini A., Di Filippo A., Schirone B. 2009. Population ecology of yew (Taxus baccata L.) in the Central Apennines: spatial patterns and their relevance for conservation strategies. Plant Ecology 205: 23-46.

Rice E.L. 1974. Allelopathy. Academic Press, New York.

Rikhari H.C., Palni L.M.S., Sharma S., Nandi S.K. 1998. Himalayan yew: stand structure, canopy damage, regeneration and conservation strategy. Environmental Conservation 25: 334-341.

Rößner H. 2009. Der Gargano am "Sporn" von Italien. Der Eibenfreund 15: 115-125.

Ruprecht H., Dhar A., Aigner B., Oitzinger G., Klumpp R., Vacik, H. 2010. Structural diversity of English yew (Taxus baccata L.) populations. European Journal of Forest Research 129: 189-198. 
Saniga M. 2000. Structure, production and regeneration processes of English yew in the State Nature Reserve Plavno. Journal of Forest Sciences 46: 76-90.

Sanz R., Pulido F., Nogués-Bravo D. 2009. Predicting mechanisms across scales: amplified effects of abiotic constraints on the recruitment of yew Taxus baccata. Ecography 32: 993-1000.

Sawyer N.W., Anderson G.J. 1998. Reproductive biology of the carrion-flower, Smilax herbacea (Smilacaceae). Rhodora 100: 1-24.

Scarnati L., Attorre F., de Sanctis M., Farcomeni A., Francesconi F., Mancini M., Bruno F. 2009. A multiple approach for the evaluation of the spatial distribution and dynamics of a forest habitat: The case of Apennine beech forests with Taxus baccata and Ilex aquifolium. Biodiversity and Conservation 18: 3099-3113.

Schirone B., Ferreira R.C., Vessella F., Schirone A., Piredda R., Simeone M.C. 2010. Taxus baccata in the Azores: A relict form at risk of imminent extinction. Biodiversity and Conservation 19: 15471565.

Silverman B.W. 1986. Density Estimation for Statistics and Data Analysis. Chapman and Hall, New York.

Svenning J.C., Magård E. 1999. Population ecology and conservation status of the last natural population of English yew Taxus baccata in Denmark. Biological Conservation 88: 173-182.

Thomas P.A., Polwart A. 2003. Taxus baccata L. Journal of Ecology 91: 489-524.

Tittensor R.M. 1980. Ecological history of yew Taxus baccata L. In Southern England. Biological Conservation 17: 243-265.

Uniyal S.K. 2013. Bark removal and population structure of Taxus wallichiana Zucc. in a temperate mixed conifer forest of western Himalaya.
Environmental Monitoring and Assessment 185: 2921-2928.

Vandermast D.B., Van Lear D.H., Clinton B.D. 2002. American chestnut as an allelopath in the southern Appalachians. Forest Ecology and Management 165: 173-181.

Vessella F., Simeone M.C., Fernandes F., Schirone A., Gomes M.P., Schirone B. 2013. Morphological and molecular data from Madeira support the persistence of an ancient lineage of Taxus baccata L. in Macaronesia and call for immediate conservation actions. Caryologia 66: 162-177.

Wani M.C., Taylor H.L., Wall M.E., Coggon P., McPhail A.T. 1971. Plant antitumor agents. VI. The isolation and structure of taxol, a novel antileukemic and antitumor agent from Taxus brevifolia. Journal of the American Chemical Society 93: 2325-2327.

Watt A.S. 1926. Yew communities of the south downs. Journal of Ecology 14: 282-316.

Yin Y., Yu R., Yang W., Yuan F., Yan C., Song L. 2010. Structural characterization and anti-tumor activity of a novel heteropolysaccharide isolated from Taxus yunnanensis. Carbohydrate Polymers 82: 543-548.

Zhang M.L., Lu X., Zhang J., Zhang S., Dong M., Huo Ch., Shi Q., Gu Y.C., Cong B. 2010. Taxanes from the leaves of Taxus Cuspidata. Chemistry of Natural Compounds 46: 53-58.

Zunzunegui M., Diaz Barradas M.C., Clavijo A., Cansino L.A., Lhout F.A., Novo F.G. 2006. Ecophysiology, growth timing and reproductive effort of three sexual forms of Corema album (Empetraceae). Plant Ecology 183: 35-46. 